\title{
Assessing the Tourists Satisfaction towards Yacht Tourism Services in the Red Sea Coast, Egypt
}

Wafaa Ahmed Elias ${ }^{a}$ Fatma Mohammed Ahmed ${ }^{\mathrm{c}}$

${ }^{a}$ Professor, Faculty of Tourism and Hotels, Minia University

${ }^{b}$ Assistant Professor, Faculty of Tourism and Hotels, Minia University

${ }^{c}$ Researcher, Faculty of Tourism and Hotels, Minia University

\section{Abstract}

This study aims to Evaluate Tourists' Satisfaction with regards to tourist services provided to them at tourist ports of the red sea. It also assesses the relationship between Yacht Service Quality and Tourist Satisfaction at The Red Sea Coast and highlights the problems faced by yachters at the tested area. This study used a questionnaire as a quantitative method which targeted the tourists who came to Egypt to practice yacht tourism in The Red Sea Coast. Statistical Package Social Science (SPSS, V.22) is used for data input and analysis in the descriptive statistics.

The results showed that there is a significant relationship between the yacht services quality, tourist satisfaction at The Red Sea Coast. The results showed also that the tourists were satisfied with: On board facilities, Pollution control Services, Marina Safety and Security facilities. They were less satisfied with: Entry \& Exit Procedures, Resort facilities and Yacht Clubs services. This study presented some recommendations for both Egyptian marinas and the ministry of tourism to increase the satisfaction degree of tourists towards yacht tourism services.

Keywords: Customer Satisfaction, Yacht Tourism, Red Sea, Egypt. 


\section{Introduction}

The yachting sector is particularly interesting as it continues to grow, displaying an ongoing positive trend since 2014 with powerboat constituting the major segment, $89 \%$ of the entire portfolio (Deloitte., 2016). The market is richly benefiting from the increasing trend towards marine tourism and luxury water-based experience. In the last ten years the global fleet is start to grow in dimension. International market researches (ECSIP Consortium., 2015, Global Industry Analysts Inc., 2016) clearly showed that the market is moving more towards the large yacht industry: between 2008 and 2016, the $60 \mathrm{~m}$ market sector, so called "mega yacht", has grown by an average of 5\%, confirming the theory that the high-end sector appears to be more resilient to any crisis in international markets (Campolongo., 2017).

Yacht tourism is a tourist style characterized by high spending and some call it the tourism of the elite and the rich and so it leads to increase tourism revenues in Egypt. There is a real goal for satisfaction of tourists that the ports administrations seek to achieved As the success achieved by the efforts in the service of the tourist. And then the study contributes to the evaluation of satisfaction degree of tourists towards these tourism services provided, which is reflected in the end to increase the frequency of visit, which would increase tourism revenues.

The objectives of this study can be summarized as follows:

1) Evaluating the satisfaction of tourists with regard to tourist services provided to them at tourist ports.

2) Assessing the relationship between yacht service quality and tourist satisfaction at The Red Sea Coast.

\section{Hypotheses of the Study:}

- H1: Yacht marinas services have high levels with $95 \%$ confidence interval for means.

- H2: Customers' satisfaction about the yacht trip have high levels with $95 \%$ confidence interval for means.

- H3: There are no statistical significant differences between research regions with regard to customers' satisfaction about the yacht trip. 


\section{Literature Review}

Parasuraman et al. (1985) described service quality as the ability of an organization to meet or exceed customer expectations. In 1981, Oliver referred customer satisfaction to the complete fulfilment of one's expectations. satisfaction may be determined by tourists' perceived comparison between the preferred expectation about a destination and the perceived evaluative experience in the destination (Yoon, \& Uysal, 2005; Kim, \& Brown, 2012).

\section{Service Quality Definition:}

Service quality defined as "the difference between the perception of the service received and expectations of customer for the service encountered in which perception and expectation are the two central elements of service quality" (Mosahab et al., 2010).

\section{Tourist Satisfaction:}

Allan (2016) defined Customer satisfaction as" the degree to which the needs, demands and expectations of customers are met in service delivery".

\section{Tourists Satisfaction Importance:}

Satisfaction is defined as an affective customer condition that results from a global evaluation of all the aspects that make up the consumer relationship (Flavin et al., 2006). Additionally, customer satisfaction is recognized as playing a vital role in predicting a customer's purchase intention, as stated by many previous studies (Chang, 2012). Moreover, Consumers' satisfaction is a key factor for establishing long-term relationships with them and acquiring their repurchase intentions (Lee et al., 2008).

\section{Models for measuring customer satisfaction}

A variety of theoretical approaches to measuring consumer satisfaction have been proposed; for instance, the expectancy disconfirmation theory, the importance- performance analysis, the equity theory, the value-percept theory, the dissonance theory and the attribution theory. A common characteristic of these measurement approaches is their consideration of satisfaction as a relative concept measured in relation to a standard such as values, inputs, experience, etc. These standards are often inputs imparted 
about by tourists, acknowledging the active involvement of individuals in the co-creation of their destination experience (Foster, 1999).

\section{Relationship between Service}

\section{Quality and Tourists Satisfaction:}

There is a strong relationship between Service Quality and Customer Satisfaction. According to (Sureshchandar et al, 2002) Service Quality and Customer Satisfaction were highly related. The relationship between service quality and satisfaction has been reported in many studies (Caruana et al., 2000; Chen, et al., 2005). According to Lin, \& Hsieh, ( 2006) Satisfaction contemplates the extent to which a consumer emanates positive sentiments to a service encounter. Both service quality and customer satisfaction are extremely related. The five SERVQUAL dimensions which were examined had a significant impact on satisfaction (Abu-El Samen et al , 2013). Service quality and also customer satisfaction are extremely related to each other. The service quality is a fundamental antecedent that connected with satisfaction. The five dimensions of SERVQUAL explored as huge constructive product on overall satisfaction. (Izogo, \& Ogba, 2015).

\section{Yachts and The needed Services:}

According to Kalemdaroglu et al.(2004) yacht tourism has a massive development potential as "it satisfies the feelings of freedom, being near to exploration, history and nature, adventure and sports." This kind of offerings can response to the changes watched in the market. The customer demand is more sophisticated, naturesensitive, claiming to join in active moods of holiday, and want to experience adventure. And yacht tourism product is the best fit for this needs.

\section{Definition of Yacht:}

The term originates from the Dutch word jacht (hunt), and was originally defined as a light fast sailing vessel used by the Dutch navy to combat pirates and other 
transgressors. It was no until the rise of the steamboat and other types of powerboat that, sailing yachts became recreational vessels.(Pardali et al.,2018).

\section{Types of Yachts:}

There are many different kinds of yachts depending on their use and size, viz. motor yachts, sailing yachts, mega yachts, etc. The length of commercial yachts or private yachts ranges from 10 meters to dozens of meters. In general, a yacht is smaller than 12 meters long, and has a maximum of 36 passengers, while a mega yacht refers to a vessel exceeding 50 meters in length (Chen et al., 2016) ( $P, 42)$.

\section{Marinas:}

Marina is a fundamental and best known type of nautical tourism harbour. As opposite to other nautical harbours which offer only boat mooring and storage services, in particularly appointed marina areas, they also offer a whole series of other facilities and services which enhance tourists' enjoyment, extend the tourist season, increase nautical and tourist expenditure and enrich the entire nautical and tourist offer (Šamanović, J., 2002).

\section{Services provided by the touristic}

ports (marinas) to ships and

passengers are

(Pardali et al.,2018):

- Port services as mooring and anchorage, well traffic sign, berths protected from the weather, boat launching ramps, warehouses, parking areas, easy access to the hinterland, dry storage areas for repairs and winter storage, safety and security systems

- Commercial port services, as water supply, bunkering, marine equipment and food supply, restaurants, bars, electricity, modern communication systems, waste reception facilities, banking services, hygiene facilities and cleaning complexes (WC and shower, laundries, dry cleaning), commercial shops, health care center, pharmacy

- Public services: customs, coast guard

- Repair services: including repair and maintenance units of the boats, technical support of electronic instruments, 
marine equipment $\&$ supplies

- Tourist-cultural and other services such as information, tourist attractions, entertainment venues, sports facilities, museums, cultural events.

\section{The specialized Marinas in the Red}

\section{Sea coast}

There are five specialized Marinas in the Red Sea coast as follows: (MARSA AlAm for Tourist Development., 2018)

\section{Port Ghalib International Marina}

Location: Port Ghalib is located on the Red Sea Governorate, $70 \mathrm{~km}$ from the town of Qusair and $60 \mathrm{~km}$ from Marsa Alam.

Services: The Marina has electronic navigation benefits, and facilities to receive ship scrapings, freshwater supplying units, electricity, communication, services of providing with fuel and oil, integrated firehouses around the quays every 300 meters, a 6- inch fire line around the quays, a double fireplug every $40 \mathrm{~m}$ on docks, also there are fire extinguisher and pump.

\section{El Gouna Marina}

Location: The Marina is located within the El Gouna Resort area in kilo 21 north of Hurghada - The Red Sea.

Services: Navigational assistance through indicative signs and there is a scrapings collection and operating, also equipment to combat marine pollution and fire. The marina has a mineral and soda water and fish and poultry farms, as well as a search and rescue center in Hurghada

\section{Hurghada Marina}

Location: Marina Hurghada- Alsakkala area- south of the port of Hurghada - is located on the west coast of the Red Sea near the entrance to the Gulf of Suez, $370 \mathrm{~km}$ south of the city of Suez.

Services: water supply facility- Electricity supply facility- Sewage facility- Sliding for small yachts.

\section{Taba Marina}

Location: Marina Taba is located on the Red Sea Governorate, 42 $\mathrm{km}$ from Nuweiba - Taba (wadi Shabla). 
Services: Waste receiving and treatment unit- Navigational aidsEquipment for fire and pollution control- treatment station-

Maintenance area.

\section{Wadi El Dom Marina}

Location: located at $80 \mathrm{~km}$ south of suez city- Ain Soukhna suez coast.

Services: water, fuel, electricity, communication supply facility, landlines, internet, boat maintenance services, and 24hour security.

\section{Yacht Tourism:}

Yachting refers to sailing boats which have a keel designed to provide a right movement via its weight. Yachts have built in accommodation (The scout information centre.,2011 ). Yachting tourism refers to the use of water vessels or boats for leisure purposes, including cruising fishing, racing, or the practice of other nautical activities. Depending on the type of vessels, it could be classified into sailing and boat powering and, depending on the property, as chartered or private yachting. (Antonio, 2016).

\section{Research Methodology}

To achieve the objectives of the study a quantitative approach was used. The Study targeted the tourists who came to Egypt to practice yacht tourism in the red sea coast. questionnaires were employed at this study to reach out the target sample during the period from January to July 2019. Questionnaire was distributed on random sample of tourists who came to Egypt to practice yacht tourism in the red sea coast. Statistical Package Social Science (SPSS, V.22) are used for data input and analysis in using descriptive statistics.

\section{The Study Findings}

A total of 225 forms of questionnaire were distributed. Only 177 forms were answered and returned back, 12 of them were excluded because they were not completed and many of tourists were not as yacht tourists. Consequently, about 165 forms were valid, completed and were included in the analysis. The data showed that the gender percentage of the respondents was $72.7 \%$ (120) male and $27.3 \%$ (45) female. According to age categories, it can be stated that the most respondents $60.6 \%$ were in the age group of 41 to 60 years. This indicates that the age group between 41 to 60 years old 
was too much interested in coming to Egypt for yachting in the red sea coast.

\section{Yacht Marinas Services descriptive}

- According to table (1) The highest three services that the tourists were satisfied about it are: Safe berths comes at the first rank (M=4.61). It includes Staff $(M=4.59)$, followed by Places for Stopping ( $\mathrm{M}=4.57)$.

- The lowest three services that the tourists were satisfied about it in yacht marinas are: Assistance with Launching of the boats and lifting them out of water as the last $(\mathrm{M}=3.55)$ , followed by Maintenance Workshop ( $\mathrm{M}=3.65)$ and High pressure jet wash $(\mathrm{M}=4.38)$.

- ninety five percent $(95 \%)$ confidence interval for mean of yacht marinas services $(\mathrm{M}=4.34)$ is between (4.2) as a lower bound and (4.4) as an upper bound, this meant that yacht marinas services have high levels, and this result supported the first hypothesis of the study.

Table (1): Statistics for yacht marinas services

\begin{tabular}{|l|l|l|c|}
\hline Items & M & SD & Ranking \\
\hline safe berths & 4.61 & 0.54 & 1 \\
\hline Staff & 4.59 & 0.53 & 2 \\
\hline Places for Stopping & 4.57 & 0.50 & 3 \\
\hline Electronic navigation aids & 4.56 & 0.50 & 4 \\
\hline The Possibility of refueling & 4.55 & 0.85 & 5 \\
\hline The Possibility of Providing clean water & 4.48 & 0.63 & 6 \\
\hline The Possibility of Providing electricity Lines & 4.45 & 0.84 & 7 \\
\hline High pressure jet wash & 4.38 & 1.70 & 8 \\
\hline Maintenance Workshop & 3.65 & 0.73 & 9 \\
\hline $\begin{array}{l}\text { Assistance with Launching of the boats } \\
\text { and lifting them out of water }\end{array}$ & 3.55 & 0.51 & 1 \\
\hline Statistics for all variables & 4.34 & 1.75 & \\
\hline
\end{tabular}

$\mathrm{M}=$ Mean SD = Standard Deviation.

\section{Satisfaction of the Trip descriptive}

The next table shows the Statistics for tourists satisfaction of their trips. From the table it can be stated that :

- The highest three items that the tourists were satisfied about it are: evaluate the level of global satisfaction 
regarding your yachting experience in the red sea

coast as the first(M=2.93), How likely the problems you met during yachting are solved by the responsible? as the second $(\mathrm{M}=2.88)$, followed by Did you receive "value for money" with your current yachting experience? $(\mathrm{M}=2.82)$.

- the lowest two items that the tourists were satisfied about it are: Are you thinking of visiting Red Sea for yachting again ? as the last $(\mathrm{M}=2.55)$, followed by How likely is it that would recommend that of trip to friends and relatives ? $(\mathrm{M}=2.82)$.

- ninety five percent (95\%)confidence interval for mean of satisfaction of the trip ( $M=2.8)$ is between (2.7) as a lower bound and (2.8) as an upper pound, this meant that satisfaction of the trip have high levels, and this result supported the ninth hypothesis of the study .

- ninety five percent (95\%)confidence interval for mean of Item $1(M=2.93)$ also achieved the first objective of this study, i.e., Evaluating the satisfaction of tourists with regard to tourist services provided to them at tourist ports.

Table (2): Statistics for satisfaction of the trip.

\begin{tabular}{|l|c|c|c|}
\hline Items & M & SD & Ranking \\
\hline please, evaluate the level of global satisfaction & & & 1 \\
regarding your yachting experience in the red & 2.9 & 0.2 & \\
sea coast? & 3 & 6 & \\
\hline How likely the problems you met during & 2.8 & 0.3 & 2 \\
yachting are solved by the responsible? & 8 & 3 & \\
\hline Did you receive "value for money" with your & 2.8 & 0.4 & 3 \\
current yachting experience? & 2 & 3 & \\
\hline How likely is it that would recommend & 2.8 & 0.3 & 4 \\
that of trip to friends and relatives ? & 2 & 8 & \\
\hline Are you thinking of visiting Red for yachting & 2.5 & 0.5 & 5 \\
again? & 5 & 3 & \\
\hline Statistics for all variables & 2.8 & 0.3 & \\
\hline
\end{tabular}

$\mathrm{M}=$ Mean SD = Standard Deviation 


\section{Descriptive Statistics for The five Marinas of The Red Sea Coast}

Table (3): statistical significant differences between

five regions of the research with regard to

customers' satisfaction about the yacht trip

\begin{tabular}{|c|l|l|l|l|l|}
\hline Variable & Region & $\begin{array}{l}\text { No. of } \\
\text { customers }\end{array}$ & $\begin{array}{l}\text { Mean } \\
\text { Rank }\end{array}$ & Chi-Squa Re & Sig. \\
\hline \multirow{2}{*}{$\begin{array}{c}\text { s' Customer } \\
\text { Satisfaction }\end{array}$} & Taba marina & 16 & 98.38 & 10.084 & 0.039 \\
\cline { 2 - 6 } & $\begin{array}{l}\text { Om el Dom } \\
\text { marina }\end{array}$ & 12 & 77.17 & & \\
\cline { 2 - 6 } & $\begin{array}{l}\text { Port Ghalib } \\
\text { marina }\end{array}$ & 69 & 71.43 & & \\
\cline { 2 - 6 } & El Gouna marina & 36 & 92.28 & & \\
\cline { 2 - 6 } & Hurghada marina & 32 & 92.00 & & \\
\hline
\end{tabular}

From the previous table it obvious that sig. value is (0.039) that means that there are significant differences between five regions of the research with regard to customers' satisfaction about the yacht trip. The results of Mann-Whitney tests indicated that there are statistical significant differences between just region of Marina Ghalib and all remaining regions, these differences are in favor of all remaining regions. This result coincided that the tenth hypothesis of the study is invalid. That means that customers' satisfaction about the yacht trip at Marina Ghalib region have low level.

\section{Discussions and Conclusion:}

The main purpose of this study is to assess the degree of satisfaction of yacht tourists in Egypt. This study aims to increase the frequency of visit, which would increase tourism revenues. Moreover, it's significance lies in the results that will be reached, which will contribute to the elimination of the problems and obstacles facing yacht tourism as well as increase the international tourist demand on them, which will increase tourism income.

The findings showed that Yacht Tourism Services quality and Satisfaction in the tourism industry are a novel and anew area of research in Egypt there are no searches in this area before.

The results showed that the highest three dimensions that the tourists were satisfied about it are: On board facilities, Pollution control Services, Marina Safety and Security facilities. 
The findings showed that the lowest three dimensions that the tourists were satisfied about it are: Entry \& Exit Procedures, Resort facilities and Yacht Clubs services.

Furthermore, The findings showed that the arrangement of The Red Sea marinas in terms of visit according to the results of the study are; Port Ghalib marina as the first

, followed by El Gouna marina, Hurghada marina, Taba marina and El Dom marina as the last.

It also showed that there is a significant relationship and a positive impact between the quality of the service, satisfaction and loyalty of tourists towards the yacht tourism services in the Red Sea coast.

Indeed, there is no difference in the degree of satisfaction according to nationalities.

\section{Recommendations:}

This study presents many recommendations for both The Egyptian Marinas and Ministry of Tourism. These recommendations can be presented as follow:

- The Egyptian Marinas should interested in developing the means of communications.

- The Egyptian Marinas must have a lot of shops for shopping.

- The Egyptian Marinas must have a clean toilets and showers.

- The Egyptian Marinas should interested in providing places to repair yachts.

- The Egyptian Marinas should interested in providing ground services and electrical current.

- The Egyptian Marinas need to develop new and creative ideas and services to offer them to their customers.

- The Ministry of tourism need to develop a computerized system links the ports which operate with the 2003 decision system.

- The Ministry of Tourism should increase the number of specialized marinas in the Red Sea.

- The Ministry of Tourism should develop a reliable tourist statistics system generally and a special department for yacht tourism statistics in particular. 


\section{References:}

- Abu-El Samen, A. A., Akroush, M. N., \& Abu-Lail, B. N. (2013). Mobile SERVQUAL: A comparative analysis of customers' and managers' perceptions. International Journal of Quality \& Reliability Management, 30(4), 403-425.

- Allan, M. M. (2016). The Relationship between Service Quality and Customer Satisfaction and Retention in Ghana's Luxury Hotels. The IUP Journal of Marketing Management, (15)4.

- Campolongo, M. (2017) House and yacht: the aesthetics of the interior as a link between different sectors. Des. J. 20(sup1), S209-S218.

- Caruana, A., Ewing, M. T., \& Ramaseshan, B. (2000). Assessment of the Three- Column Format SERVQUAL: An Experimental Approach. Journal of Business Research, 49(1), 57-65. https://doi.org/10.1016/S0148-2963(98)00119-2

- Chang, K. (2012). Examining the Effect of Tour Guide Performance, Tourist Trust, Tourist Satisfaction, and Flow Experience on Tourists' Shopping Behavior Examining the Effect of Tour Guide Performance, Tourist Trust, Tourist Satisfaction, and Flow Experience on Tour. Tourism Research, 19(June 2015), 37-41.

- Chen J. M., Balomenou C., Nijkamp P., Poulaki P. and Lagos D., (2016), The Sustainability of Yachting Tourism: A Case Study on Greece, International Journal of Research in Tourism and Hospitality (IJRTH),. Volume 2, Issue 2, 2016, PP 42-49, dx.doi.org/10.20431/2455-0043.0202005.

- Chen, Y. F., Hsiao, C. H., \& Lee, W. C. (2005). How does student satisfaction influence student loyalty- from the relationship marketing perspective. rnd2. ncue. edu. tw/ezcatfiles/b004/img/img/316/96-1-4p. com

- Deloitte: (2016) Market insight of the international recreational boating industry.

- $\quad$ Deng Z., Lu Y., Wei K.K., Zhang J., 2010. Understanding customer satisfaction and loyalty: An empirical study of mobile instant messages in China. International Journal of Information Management, 30(4),289-300. 
doi:10.1016/j.ijinfomgt.2009.10.001

- ECSIP Consortium: (2015) Study on the competitiveness of the recreational boating sector.

- Flavin, C., Guinalu, M., \& Gurrea, R. (2006). The role played by perceived usability, satisfaction and consumer trust on website loyalty. Information and Management, 43(1), 1-14.

- Foster, D. (1999). Measuring customer satisfaction in the tourism industry. Paper presented at The Third International and Sixth National Research Conference on Quality Management, Melbourne, February 8-10, 1999.

- Global Industry Analysts Inc (2016) Yacht Industry. In A global strategic business report.

- Izogo, E. E., \& Ogba, I.-E. (2015). Service quality, customer satisfaction and loyalty in automobile repair services sector. International Journal of Quality \& Reliability Management, 32(3), 250-269.

- Kalemdaroglu, A. E., Seker, D. Z. and Kabdasli, S. (2004), GIS Based Inventory of Marinas on The Coastal Region of Turkey Coastal Region of Turkey, ISPRS XXth Congress, Istanbul, Turkey.

- Kim, A. K. \& Brown, G. (2012). Understanding the relationships between perceived travel experiences, overall satisfaction, and destination loyalty. Anatolia - An International Journal of Tourism and Hospitality Research, 23(3), 328-347

- $\quad$ Lee, Y., Lee, C., Lee, S., \& Babin, B. (2008). Festivalscapes and patrons' emotions, satisfaction, and loyalty. Journal of Business Research, 61, 56-64.

- Lin, J.-S. C., \& Hsieh, P.-L. (2006). The role of technology readiness in customers' perception and adoption of self service technologies. International Journal of Service

- MARSA AlAm for Tourist Development. Port Ghalib International Marina,( 2018) Comparison between the specialized ports in the Red Sea www.portghalibmarina.com.

- Mosahab R., Mahamad O., Ramayah T, 2010. Service Quality, Customer Satisfaction and Loyalty: a Test of 
Mediation. International Business Research, 3(4), 72-80. doi:10.5539/ibr.v3n4p72.

- Oliver, R. L. (1981). Measurement and evaluation of satisfaction processes in retail settings. Journal of Retailing, 57(3), 25-48.

- Pardali, A., Giantsi, T. (2018). The Formation of Maritime Tourism (Yachting) Cluster as a Vehicle for Competitiveness Improvement: The Greek Case. International Journal of Research in Tourism and Hospitality (IJRTH) Volume 4, Issue 1, 2018, PP 64-74 ISSN 2455-0043 http://dx.doi.org/10.20431/2455- $\quad 0043.0401008$ www.arcjournals.org

- Šamanović, J., (2002), Nautički turizam i management marina, Split: Visoka pomorska škola.

- Sureshchandar, G.S., Rajendran, C. and Anantharaman, R.N. (2002), "Determinants of customerperceived service quality: a confirmatory factor analysis approach", Journal of Services Marketing, Vol. 16 No. 1, pp. 9-34.

- The scout information centre., (2011) Yachting, What is Yachting?, September 10th, 2011;3, www.scoutbase.org.uk (accessed05.02.2011)

- Tong, W. (2015). Analyzing the relationship between Customer Satisfaction and Customer Loyalty Case: RitzCarlton Guangzhou. Thesis submitted for fulfillment of degree programme in Business Management in Lapland University of Applied Sciences.

- Yoon, Y. and Uysal, M. (2005) 'An Examination of the Effects of Motivation and Satisfaction on Destination Loyalty: A Structural Model', Tourism Management 26: 45-56. 